\title{
КОНЦЕПТУАЛЬНІ ТА ПРАКТИЧНІ ЗАСАДИ ДЕРЖАВНОЇ КАДРОВОЇ ПОЛІТИКИ УКРАЇНИ У СФЕРІ ОСВІТИ
}

\author{
Чорномаз I. К., кандидат технічних наук, Черкаський інститут пожежної безпеки імені \\ Героїв Чорнобиля Національного університету цивільного захисту України, Черкаси, Україна \\ Григор'ян М. Б., кандидат технічних наук, Черкаський інститут пожежної безпеки імені \\ Героїв Чорнобиля Начіонального університету цивільного захисту Украӥни, Черкаси, Україна \\ Гончар С. В., Черкаський інститут пожежної безпеки імені Героїв Чорнобиля Національного \\ університету цивільного захисту Украӥни, Черкаси, Україна
}

\section{DOI: https://doi.org/10.31435/rsglobal_conf/25022021/7417}

\begin{abstract}
At this stage of Ukraine's development there is a need for stabilization and sustainable development of Ukrainian society, which requires solving the problem of improving personnel policy. One of the main causes of negative phenomena in society is the imperfection of personnel policy in the field of education, increasing bureaucratization, improper performance of the state function of social protection.

Despite the fact that a lot of time has passed since the beginning of social transformations in our country, the study of the problem of the effectiveness of state personnel policy by the social and political sciences is insufficient. Changes in the socio-political system raise the question of whether the civil service is becoming an instrument of professional management activities aimed at meeting the new social needs of society. Under these conditions, there is a need for a new personnel policy of selection and formation of a qualitatively new personality of the education worker.
\end{abstract}

Keywords: personnel policy, foreign practice of personnel management processes, personnel processes, personnel technologies, public authorities, public service.

Вступ. В Україні опубліковано чимало наукових праць про державну кадрову політику та іï аналіз. Серед дослідників проблем державної політики потрібно назвати В. Гальперину, В. Ребкала, Т. Брус, Л. Прокопенка, В. Романова, О. Рудіка, В. Тертичка. Дослідженням теоретико-методологічних засад державної політики в галузі кадрової політики присвятили свої праці В. Андрющенко, В. Дарманський, Д. Дзвінчук й інші вітчизняні науковці. Зазначені проблеми активно досліджують відомі в цій галузі зарубіжні фахівці А. Адамський, А. Бардашкевич, П. Браун тощо.

Поняття «державна кадрова політика в галузі освіти» почало використовуватися у науковій літературі 60 - 70-х pp. ХХ ст., коли у СРСР, США, державах Європи та в Японії освіту почали розглядати як найважливіший чинник економічного розвитку й соціального прогресу, як сферу, що потребує особливої уваги на загальнодержавному рівні. Цей період характеризується «інформаційним вибухом», тобто бурхливим розвитком природничих i фізико-математичних наук. Принциповою особливістю державної політики в ці роки стає пріоритетність фінансування системи освіти й визнання ії сферою національних інтересів. Державні витрати на освіту в усьому світі зростають більш як у 12 разів.

У ВВП усіх передових країн світу частка цих витрат підвищується до початку 80-х рр. до 5,7\% порівняно з 3,6\% у 1960 р. Тоді ж у освітній політиці різних держав з'являється така особливість, як планування розвитку державної освіти.

На думку багатьох дослідників, передумовами того, що державні інституції почали цілеспрямовано формувати державну кадрову політику стали: перехід людства від індустріального до постіндустріального суспільства; раціоналізація професійної діяльності кадрів; зокрема, посилення взаємозв'язку виховання та освіти, культури й освіти, ментальності й освіти як способи збереження i розвитку цивілізованості окремих держав; альтернативність розвитку самого освітнього процесу, його комплексність, системність і структурованість змістовного й організаційного порядку; збагачення досвідом на дання освітніх послуг; інформатизація громадського життя загалом; інноваційність розвитку системи. Із впливом цих об'єктивних обставин пов' язане виникнення у 60-70-ті рр. ХХ ст. освітньої політики сучасних держав.

Як відомо існує необхідність в удосконаленні кадрової політики в напрямку зміни концепції підготовки кадрів як інструмента формування владної еліти. На сучасному етапі трансформації суспільства відбувається реформування його інститутів. В наслідок цього змінюються також завдання державного управління. Однією з головних причин негативних 
явищ у суспільстві є недосконалість кадрової політики в галузі державного управління, зростання бюрократизації, неналежне виконання державою соціально захисної функції.

Результати досліджень. Незважаючи на те, що від початку суспільних перетворень в Україні пройшло вже чимало часу, висвітлення в науковій політологічній літературі проблеми ефективності державної кадрової політики є недостатнім. Зміни у системі суспільно-політичного устрою порушують питання про те, чи стає державна служба типом професійної управлінської діяльності, спрямованим на задоволення нових соціальних потреб суспільства. За цих умов виникає потреба у формуванні якісно нової особистості працівника державної служби.

В умовах соціальної трансформації особливого значення набуває розвиток системи вищої освіти у підготовці управлінських кадрів як необхідної умови реалізації їх функцій в державному управлінні.

У всі часи держава приділяла особливу увагу системі освіти, якав різних соціальноекономічних i соціокультурних умовах виконує соціальне замовлення на формування особистості. Тому ідеали професійних кадрів відмінні один від одного. Пильна увага держави до системи кадрової служби зумовлена тим, що остання отримує державне замовлення на формування особистості визначеного типу. Освіта, яка для сучасного суспільства становить загально-соціальну цінність, вже не має колишнього інструментального значення. Втрачаються позиції за якістю освіти, стимулами іiі здобуття та фаховою різноманітністю. Це при тому, що світовою тенденцією початку нинішнього тисячоліття $€$ визнання того, що розвиток людського потенціалу є основним ресурсом сталого економічного зростання і конкурентоспроможності у довготерміновій перспективі. Це довела і нещодавня світова фінансово-економічна криза.

Вивчення процесів формування державної освітньої політики показує, що загалом політика може розглядатися як форми, завдання, зміст діяльності держави, утілення нею власних повноважень. Саме тому формування державної освітньої політики охоплює такі етапи:

1) визначення принципових завдань;

2) накреслення перспективних i найближчих цілей, які мають бути досягнуті у конкретний термін;

3) вироблення методів, засобів, форм діяльності;

4) вибір організацій (інституцій), за допомогою котрих здійснюватиметься діяльність і можуть бути досягнуті поставлені цілі;

5) підбір і розстановка кадрів, здатних зрозуміти й виконати накреслені завдання. Безумовно, ці позиції передбачають аналіз конкретної ситуації, перегляд (добір) можливих варіантів вирішення поставлених завдань.

На нашу думку, така інтерпретація політики об'єднує в одне ціле саму політику, іiі розробку i, головне, реалізацію. Для формування та реалізації державної освітньої політики потрібно також визначити принципи, на яких грунтується державна політика у галузі освіти.

Принципи та цілі освітньої політики вирізняються найбільшою статичністю. Їх зміна, як правило, є наслідком зміни чи серйозного коригування політичного курсу. А дії суспільства й держави щодо розвитку системи освіти в досягненні декларованих цілей повинні змінюватися досить динамічно, адекватно реагуючи на різні чинники. Тому, характеризуючи освітню політику, важливо не тільки, і навіть не стільки вивчати декларовані цілі, скільки аналізувати реальні дії та конкретні результати розвитку освітньої системи.

В умовах нинішнього оновлення змісту освіти й підвищення іï якості звернення до аналізу минулих реформ $є$ доречним. Важливо, усуваючи наслідки ідеї піднесення теоретичного рівня освіти (перевантаженість навчальних планів і програм), не переорієнтовувати сучасну освіту із загальнокультурного змісту 3 його фундаментальними основами на формування лише конкретних практичних навиків.

Освітня політика не здатна видати миттєвий результат. Проте вона, як і будь-яка діяльність, що забезпечує кінцевий продукт, може й повинна піддаватися моніторингу. Складність оцінки системи освіти, як і освітньої політики загалом, полягає в тому, що їхні соціальні наслідки виявляються як соціальні внески через $15-20$ років. Таким чином, освіта $\epsilon$ найважливішим напрямом державної політики України, оскільки саме на освіту покладені завдання 3 формування та розвитку людського потенціалу країни, примноження інтелектуального ресурсу нації, створення умов для духовного самоствердження особистості.

Освіта $€$ ключовим фактором суспільного прогресу, джерелом розробки новітніх гуманітарних технологій, засобом формування знань і вмінь, які мають попит на світовому ринку 
праці, $є$ інструментом розвитку громадянського суспільства. На необхідності реформування вітчизняної системи освіти вже багато років наголошують провідні науковці, громадські діячі, політики, прості громадяни. Питання реформування освіти в Україні обговорюється не один рік. Серед чинників, що «гальмують» реформування, зазначають недостатнє фінансування, відсутність дієвої нормативно-правової основи освітніх реформ, територіальну та ментальні особливості, подрібненість та розпорошеність системи освіти як у рівневому, так і в галузевому аспектах тощо.

Говорячи про реформування освіти України, на перший план висувається питання ефективності запровадження змін. Безумовно, величезна роль у цьому випадку належить кадрам освіти, які безпосередньо розробляють та реалізують державну освітню політику.

Результати дослідження. Метою освіти $є$ всебічний розвиток людини як особистості та найвищої цінності суспільства, іiі талантів, інтелектуальних, творчих і фізичних здібностей, формування цінностей і необхідних для успішної самореалізації компетентностей, виховання відповідальних громадян, які здатні до свідомого суспільного вибору та спрямування своєї діяльності на користь іншим людям і суспільству, збагачення на цій основі інтелектуального, економічного, творчого, культурного потенціалу Українського народу, підвищення освітнього рівня громадян задля забезпечення сталого розвитку України та їі європейського вибору.

Освіта є найважливішим напрямом державної політики України, оскільки саме на освіту покладені завдання з формування та розвитку людського потенціалу країни, примноження інтелектуального ресурсу нації, створення умов для духовного самоствердження особистості.

Освіта $є$ ключовим фактором суспільного прогресу, джерелом розробки новітніх гуманітарних технологій, засобом формування знань і вмінь, які мають попит на світовому ринку праці, $є$ інструментом розвитку громадянського суспільства.

На необхідності реформування вітчизняної системи освіти вже багато років наголошують провідні науковці, громадські діячі, політики, прості громадяни. У 20-й ювілейній Доповіді з людського розвитку Програми розвитку ООН (2010р.) зазначається, що в Україні лише $38 \%$ населення задоволено освітньою системою і школами.

Питання реформування освіти в Україні обговорюється не один рік. Серед чинників, що «гальмують» реформування, зазначають недостатнє фінансування, відсутність дієвої нормативно-правової основи освітніх реформ, територіальну та ментальні особливості, подрібненість та розпорошеність системи освіти як у рівневому, так і в галузевому аспектах тощо. Говорячи про реформування освіти України, на перший план висувається питання ефективності запровадження змін. Безумовно, величезна роль у даному випадку належить кадрам освіти, які безпосередньо розробляють та реалізують державну освітню політику.

За кількістю працюючих освіта є найбільшою гуманітарною сферою і другою - після промисловості. За матеріалами Національної доповіді про стан і перспективи розвитку освіти в Україні (2011 р.) загальна кількість працівників освіти становить 1,6 млн. Близько 1 млн осіб серед них становлять педагогічні і науково-педагогічні працівники. Останні розподілені так: 140 тис. дошкільна освіта, 520 тис. - загальна середня освіта, 25 тис. - позашкільна освіта, 45 тис. - професійно-технічна освіта, 200 тис. - вища освіта, 25 тис. - післядипломна освіта. Зазначені показники ще раз ілюструють необхідність запровадження виваженої та обгрунтованої державної кадрової політики в освіті.

Державна кадрова політика в освіті - це сукупність принципів, способів, дій державних органів управління освітою з організації людських ресурсів галузі на основі формування, підтримки і розвитку освітніх цінностей та ідеалів, норм, правил, процедур, здатних забезпечити цілісність та стійкість розвитку системи освіти у відповідності з державними цільовими установками.

Реформування кадрового забезпечення системи освіти є одним з пріоритетів державної кадрової політики України. Плани конкретних заходів щодо реалізації державної кадрової політики в освіті знайшли відображення у Національній доктрині розвитку освіти, Білій книзі національної системи освіти України, Національній доповіді про стан і перспективи розвитку освіти в Україні, матеріалах III Всеукраїнського з'їзду працівників освіти та ін. Необхідність глибокого аналізу кадрової політики галузі освіти та вироблення практичних рекомендацій щодо реалізації поставлених державою завдань вимагає визначення основних напрямів реформування системи кадрового забезпечення освіти України.

На сьогодні в Україні кожний обласний центр здійснює підготовку вчителів та вихователів. Щороку дипломи спеціалістів і магістрів отримують сотні тисяч випускників 
педагогічних вищих навчальних закладів (ВН3). Проте практика демонструє картину колосальної нестачі педагогічних кадрів як у дошкільній, так і в загальній середній освіті. Особливо актуальною ця проблема $\epsilon$ для навчальних закладів сільської місцевості. За цього рівень працевлаштування випускників педагогічних спеціальностей за даними 2018 р. становить лише $80-85 \%$. Так, на сьогодні лише $68 \%$ педагогів у системі позашкільної освіти мають вищу освіту, при цьому серед керівників ПНЗ частка осіб із вищою освітою становить 96,7\%.

За даними департаменту економіки та фінансування Міністерства освіти і науки України загальна кількість учителів у 2016/2017 навчальному році становила 406237 педагогів Це на 4612 освітян менше, ніж у 2015/2016 навчальному році.

Головною метою діяльності закладів системи ПТО є підготовка конкурентоспроможних кваліфікованих робітників. Це вимагає системної роботи у напрямі наближення ПТО до виробництва, перегляду низки освітніх стандартів, відповідної підготовки кадрів для системи ПТО. Особливої уваги потребує система кадрового забезпечення ВНЗ. Станом на 2017 2018 pp. у ВНЗ I і II рівнів акредитації працювало 37 тис., зокрема 1 тис. (85\%) штатних, педагогічних працівників та відповідно 225 і 199 (88\%) науково-педагогічних працівників. Внаслідок цього на сьогодні на часі прийняття низки нормативних документів, які б регламентували післядипломну освіту працівників ВНЗ. Це, зокрема, закони: «Про освіту», «Про освіту дорослих», «Про вищу освіту» тощо.

Неможна залишити поза увагою низький рівень заробітної плати освітян. За даними Державної служби статистики України (2018р.), з 20 видів і підвидів економічної діяльності освіта посідає 14 місце за рівнем середньої заробітної плати. Безумовно, зазначена проблема не вирішується на рівні конкретного навчального закладу, а потребує системної роботи усіх інституцій держави. Так, реалізація освітніх реформ актуалізувала питання професіоналізму керівних кадрів освіти.

На сьогодні в Україні є сформованою мережа закладів післядипломної педагогічної освіти, що реалізують програми підвищення кваліфікації педагогічних і науково-педагогічних працівників. Але на часі підготовка управлінців-практиків для системи управління освітою фахівців із розробки та реалізації державної політики в галузі освіти. Перший крок у цьому напрямі було зроблено у 2009 р. НАДУ із відкриттям нової спеціальності за магістерською програмою «Державне управління у сфері освіти», що зорієнтована на професійну підготовку керівних кадрів освіти. На жаль, досить не визначеними залишаються питання професійної управлінської підготовки керівних кадрів регіонального і місцевого рівнів управління освітою, що передбачає розробку нових оригінальних навчальних програм і курсів.

Таким чином, потрібно зазначити, що система кадрового забезпечення освіти України потребує невідкладного реформування. За цього необхідним $є$ проведення системної роботи у таких напрямах:

1. Розробка науково обгрунтованої концепції сучасної кадрової політики в освіті, запровадження положень стратегічного управління кадровим потенціалом в освіті.

2. Удосконалення нормативно-правової та організаційної бази кадрової політики в освіті, прийняття низки нормативно-правових документів, які б регламентували підготовку, перепідготовку та підвищення кваліфікації педагогічних, науково-педагогічних та керівних кадрів освіти, їх працевлаштування, соціальний захист тощо.

3. Модернізація системи неперервної професійної освіти педагогів, зокрема оновлення стандартів вищої педагогічної освіти, введення нової системи атестації педагогічних, науково педагогічних працівників і керівних кадрів освіти, складовими якої є оцінка професійної компетентності, теоретичної підготовки тощо.

4. Співпраця держави та громадськості у напрямі прийняття та реалізації управлінських рішень, контролю за їх виконанням, участь в оцінці якості освіти споживачами освітніх послуг тощо.

Стратегічною метою державної кадрової політики у сфері освіти, як вже було згадано вище, має стати не лише підготовка і висока кваліфікація управлінських, педагогічних і науковопедагогічних кадрів освіти, забезпечення і зберігання балансу процесів кількісного і якісного складу освітянських кадрів відповідно до потреб розвитку суспільства, системи освіти, вимог чинного законодавства, стану економіки країни, а й відновлення в суспільстві соціального престижу, статусу педагогічної і науково педагогічної діяльності. А отже, у структурнозмістовому плані державна кадрова політика - це система офіційно визнаних цілей, завдань, пріоритетів і принципів діяльності держави з організації та регулювання кадрових процесів $\mathrm{i}$ 
відносин. Державна кадрова політика реалізується через сукупність різноманітних соціальних функцій владних інститутів і визначає шляхи і засоби кадрового забезпечення реформ, професіоналізм їх здійснення; є важливим фактором збереження та зміцнення цілісності держави, соціально-політичної стабільності суспільства та елементом регуляції життєдіяльності населення.

Об'єктом впливу кадрової політики держави є всі кадри суспільства, усі людські ресурси. Кадри поєднують професійно підготовлені групи людей, що здійснюють діяльність у різних сферах суспільства. Вони є складним утворенням, що зумовлює соціальну стратифікацію суспільства. Кадри класифікуються відповідно до професійної структури суспільства на кадри: державно-політичної сфери, матеріально-господарської сфери і соціально-культурної сфери. Відповідно до ієрархії управління розрізняють керівників, фахівців і виконавців. До об'єктів кадрової політики належить також комплекс відповідних правових норм, принципів, форм, методів і засобів, спрямованих на забезпечення реалізації мети, цілей і завдань, які визначаються кадровою політикою всіх рівнів. Кадрова політика орієнтована на підтримку та внесення змін у функціонування кадрової системи держави, регуляцію кадрових процесів, забезпечення взаємодії суб'єктів кадрової політики та кадрової роботи.

Особливе місце серед шляхів реалізації Стратегії посідає підвищення ролі молоді як пріоритетного напряму розвитку кадрового потенціалу держави, від якого багато в чому залежить реформування та оновлення, стабілізація та розвиток українського суспільства. Формування та реалізація державної кадрової політики має здійснюватися на засадах системної діяльності, яка поєднує науково-методологічні, політико-правові, соціально-економічні, морально-психологічні, соціокультурні, управлінські та інноваційні аспекти.

Державна кадрова політика - цілеспрямована, розрахована на тривалий період стратегічна діяльність держави 3 формування, збереження, нарощування, розвитку та раціонального використання кадрового потенціалу суспільств.

Державна галузева кадрова політика - складова державної кадрової політики, що базується на державних пріоритетах з урахуванням галузевих особливостей та потреб і відповідних ресурсів.

Державна служба в Україні - професійна діяльність осіб, які обіймають посади в державних органах та їх апараті щодо практичного виконання завдань і функцій держави та одержують заробітну плату за рахунок державних коштів.

Державне управління - процес діяльності органів державної влади, спрямований на регулювання суспільних відносин. У широкому розумінні державне управління охоплює органи виконавчої влади, органи місцевого самоврядування, судової влади, прокуратури та інші органи державної влади. У вузькому розумінні - тільки органи виконавчої влади.

Державний службовець України - особа, що перебуває у публічно-правових відносинах із державою. Кадри - штатний склад працівників різних сфер суспільної діяльності, які мають відповідну професійну підготовку, практичні навички або досвід роботи в певній сфері діяльності та забезпечують досягнення цілей організації. У більш професійному розумінні кадри - це частина найбільш здібного, професійно підготовленого персоналу установи, організації, підприємства, які наділені відповідним статусом та виконують як виробничі, так і розпорядчо-управлінські й керівні функції.

Кадрова політика - цілеспрямована, розрахована на тривалий період стратегічної діяльності із формуванням, збереженням, розвитком та використанням людських, трудових, кадрових ресурсів, а також ресурсне забезпечення ії реалізації. Принципи кадрової політики сформульовані на основі вітчизняного і зарубіжного досвіду правила, покладені в основу діяльності суб'єктів із розробки і реалізації кадрової політики держави, відомства, установи, організації, підприємства тощо. Професіоналізм персоналу - здатність працівників, які мають необхідний набір навичок, знань, цінностей, підходів та особистих якостей, що проявляються у їх поведінці, виконувати види робіт, які входять до компетенції посад, що ними обіймаються.

Отже, державна кадрова політика має реалізовуватися на засадах:

- системної діяльності, яка поєднує політико-правові, економічні, соціальні, організаційні, морально-психологічні, соціокультурні аспекти;

- універсальності для всіх суб'єктів державної кадрової політики;

- єдності цілей, принципів, форм і методів роботи з кадрами;

- орієнтованості на забезпечення реалізації моделі української економіки найближчого і віддаленого майбутнього; 
- цілеспрямованої професіоналізації трудових ресурсів і кадрової системи;

- соціального партнерства всіх суб'єктів державної кадрової політики;

- постійного удосконалення кадрової системи, розвитку ії інститутів із метою ефективного використання всіх форм суспільної взаємодії;

- оптимального поєднання забезпечення стабільності кадрів та їх раціонального оновлення;

- використання кращого вітчизняного та світового досвіду кадрової роботи;

- сучасного технологічного та ресурсного забезпечення.

Таким чином, важливий напрям кадрової політики в контексті відтворення та ефективної реалізації кадрового потенціалу - стимулювання розвитку самоосвіти кадрів. Потреба в державному впливі на розвиток самоосвіти зумовлюється суспільною та особистісною необхідністю, зростанням ролі освіти в життєдіяльності особистості й суспільства в сучасних умовах його розвитку. наступні.

До найактуальніших проблем у кадровому забезпеченні освіти України можна віднести

1. Підготовка вчителів для системи дошкільної та загальної середньої освіти. Дошкільна та загальна середня освіта $є$ тими ланками системи освіти, які зорієнтовані на найбільшу кількість учасників навчально-виховного процесу, у найдовший за часом термін. Дошкільна та загальна середня освіта виконує функції створення бази для формування гармонійної особистості та можливостей ії ефективного розвитку і соціальної адаптації. Провідна роль у цьому процесі належить вчителю-вихователю.

Сьогодні в Україні кожний обласний центр здійснює підготовку вчителів та вихователів. Щороку дипломи спеціалістів і магістрів отримують сотні тисяч випускників педагогічних вищих навчальних закладів (ВН3). Проте практика демонструє картину колосальної нестачі педагогічних кадрів як у дошкільній, так і в загальній середній освіті. Особливо актуальною ця проблема є для навчальних закладів сільської місцевості. При цьому рівень працевлаштування випускників педагогічних спеціальностей за даними 2016 р. становить лише $80-85 \%$.

Причини такої ситуації полягають у системі кадрової роботи. I справа не лише у фінансуванні освіти за «залишковим принципом». Сучасна ситуація щодо забезпечення кадрами дошкільної та загальної середньої освіти потребує перегляду принципів кадрової політики в освіті, відновлення в суспільстві авторитету вчителя, підвищення ролі громадськості у прийнятті рішень, пов'язаних із діяльністю навчальних закладів, запровадження системи обліку кадрів для дошкільної та загальної середньої освіти, починаючи із випускників ВН3, створення умов для професійного та особистісного розвитку вчителів і вихователів, розвитку системи післядипломної освіти педагогів, розробки компетентнісного підходу в освіті тощо.

2. Підготовка педагогічних працівників для системи позашкільної освіти. Досить тривала непланомірність, недооцінка державної підтримки цієї важливої ланки освіти для розвитку, виховання, навчання і професійного самовизначення молоді призвели до того, що на сьогодні відсутнє об'єктивне оцінювання потреби у фахівцях для різнопрофільних позашкільних навчальних закладів (ПНЗ).

Актуальним залишається питання здобуття повної вищої освіти педагогічними працівниками позашкільних навчальних закладів. Так, на сьогодні лише $68 \%$ педагогів у системі позашкільної освіти мають вищу освіту, при цьому серед керівників ПНЗ частка осіб 3 вищою освітою складає $96,7 \%$.

Водночас треба зазначити, що позитивна тенденція до зростання частки педагогічних кадрів ПНЗ з вищою освітою за останні п’ять років зовсім незначна. Вирішення завдання професійної підготовки фахівців для позашкільної освіти вбачається в активному запровадженні у вищих навчальних закладах нових спеціальностей та спеціалізацій, розробленні навчальних програм і спецкурсів з питань позашкільної освіти, оптимізації мережі закладів післядипломної педагогічної освіти.

Особливої уваги потребують питання професійної підготовки керівних кадрів центральних, регіональних органів виконавчої влади та органів місцевого самоврядування, які несуть відповідальність за державне регулювання розвитку позашкільної освіти.

3. Підготовка кадрів для системи професійно-технічної освіти (ПТО).

Головною метою діяльності закладів системи ПТО є підготовка конкурентоспроможних кваліфікованих робітників. Це вимагає системної роботи у напрямі наближення ПТО до виробництва, перегляду низки освітніх стандартів, відповідної підготовки кадрів для системи 
ПТО. Сьогодні у 975 професійно-технічних училищах України, що готують професійні кадри за 35 напрямами і видами господарської діяльності, працює понад 45 тис. педагогічних працівників. При цьому контингент управлінських кадрів для ПТО формується головним чином із числа спеціалістів інженерно-технічного та інших профілів, які не мають відповідної економічної і управлінської освіти.

4. Особливої уваги потребує система кадрового забезпечення ВНЗ. Станом на 2016/2017 р. у ВНЗ I і ІІ рівнів акредитації працювало 37 тис., у тому числі 31 тис. (85\%) штатних, педагогічних працівників та відповідно 225 і 199 (88\%) науково-педагогічних працівників. Кількість кандидатів і докторів наук становила відповідно 2,8\% і 0,2\%, доцентів - 1,1\%, професорів - 0,2\%. У ВНЗ III і IV рівнів акредитації викладали 164 тис., з них 140 тис. (86\%) штатних, педагогічних і науково-педагогічних працівників. Серед викладачів BHЗ III і IV рівнів акредитації $41 \%$ кандидатів і 8,2\% докторів наук, 2,7\% доцентів і 7,4\% професорів.

Зважаючи на велику кількість студентів, що навчаються у ВН3, така кількість педагогічних і науково-педагогічних кадрів $є$ недостатньою. Потребує суттєвого удосконалення якісний склад науково-педагогічних та керівних кадрів системи вищої освіти.

В Україні нині не існує чіткої, узгодженої та дієвої системи підвищення кваліфікації викладачів та керівників ВНЗ. Діюча практика стажування викладачів у інших профільних навчальних закладах не дає бажаного ефекту, оскільки в процесі такого стажування не реалізується компетентнісний підхід до професійного розвитку фахівця вищої школи. Досить часто таке стажування має формальний характер. Потребують суттєвого перегляду навчальні програми підвищення кваліфікації для працівників вищої школи, зокрема в частині осучаснення змісту навчання, надання йому практичної спрямованості.

Нагальною є переорієнтація методів навчання на розвиток самоосвіти, самопізнання, саморозвитку фахівців вищої школи. У зв'язку з цим сьогодні на часі прийняття низки нормативних документів, які б регламентували післядипломну освіту працівників ВНЗ. Це, зокрема, закони «Про освіту дорослих», «Про вищу освіту» та ін.

Не можна залишити поза увагою низький рівень заробітної плати освітян. За даними Державної служби статистики України), з 20 видів і підвидів економічної діяльності освіта посідає 14 місце за рівнем середньої заробітної плати. Безумовно, зазначена проблема не вирішується на рівні конкретного навчального закладу, а потребує системної роботи усіх інституцій держави.

5. Реалізація освітніх реформ актуалізувала питання професіоналізму керівних кадрів освіти. На сьогодні в Україні є сформованою мережа закладів післядипломної педагогічної освіти, що реалізують програми підвищення кваліфікації педагогічних і науково-педагогічних працівників. Але на часі підготовка управлінців-практиків для системи управління освітою фахівців з розробки та реалізації державної політики в галузі освіти. Перший крок у цьому напрямі було зроблено у 2009 р. НАДУ із відкриттям нової спеціальності за магістерською програмою «Державне управління у сфері освіти», що зорієнтована на професійну підготовку керівних кадрів освіти. Запроваджена в НАДУ спеціальність «Державне управління у сфері освіти» не має аналогів в Україні. Відтак розробка науково-методичної бази підготовки керівників освіти $є$ нагальною проблемою розвитку цього напряму кадрового забезпечення системи освіти.

Також невизначеними залишаються питання професійної управлінської підготовки керівних кадрів регіонального і місцевого рівнів управління освітою, що передбачає розробку нових оригінальних навчальних програм і курсів.

Підсумовуючи, слід зазначити, що система кадрового забезпечення освіти України потребує невідкладного реформування.

При цьому необхідним $є$ проведення системної роботи у таких напрямах:

1. Розробка науково обгрунтованої концепції сучасної кадрової політики в освіті, запровадження положень стратегічного управління кадровим потенціалом в освіті.

2. Удосконалення нормативно-правової та організаційної бази кадрової політики в освіті, прийняття низки нормативно-правових документів, які б регламентували підготовку, перепідготовку та підвищення кваліфікації педагогічних, науково-педагогічних та керівних кадрів освіти, їх працевлаштування, соціальний захист тощо.

3. Модернізація системи неперервної професійної освіти педагогів, зокрема оновлення стандартів вищої педагогічної освіти, введення нової системи атестації педагогічних, науковопедагогічних працівників і керівних кадрів освіти, складовими якої $є$ оцінка професійної компетентності, теоретичної підготовки тощо. 
4. Співпраця держави і громадськості у напрямі прийняття та реалізації управлінських рішень, контролю за їх виконанням, участь в оцінці якості освіти споживачами освітніх послуг тощо.

5. Підвищення ефективності фінансування освіти.

Стратегічною метою державної кадрової політики у сфері освіти має стати не лише підготовка і висока кваліфікація управлінських, педагогічних і науково-педагогічних кадрів освіти, забезпечення і зберігання балансу процесів кількісного і якісного складу освітянських кадрів відповідно до потреб розвитку суспільства, системи освіти, вимог чинного законодавства, стану економіки країни, а й відновлення в суспільстві соціального престижу, статусу педагогічної і науково-педагогічної діяльності.

Висновки. Підсумовуючи, необхідно зазначити, що в сучасних умовах державна кадрова політика повинна стати прискорювачем соціально-демократичних перетворень, центром усього управлінського процесу.

Цілі та принципи кадрової політики можуть стати мобілізуючою й організуючою силою в координації і взаємодії всіх державних, економічних і громадських структур у вирішенні кадрових питань, у формуванні, розвитку та раціональному використанні всього кадрового потенціалу, зокрема управлінського і підприємницького.

Отже, послідовне і цілеспрямоване формування державної кадрової політики, особливо в регіонах, позначається на реалізації завдань адміністративної реформи, на покращанні якісного складу кадрів державної служби, їх професійно-інтелектуальному рівні і результатах роботи в здійсненні ринкових реформ.

Державна кадрова політика здійснюється уповноваженими державними органами, визначають мету, завдання, виробляють принципи здійснення державної кадрової політики, визначають місце і роль кадрів у суспільстві, нормативно-правові засади та критерії оцінки їх діяльності, створюють систему механізмів розвитку кадрового потенціалу, удосконалення його професіоналізму, морально-етичних якостей.

Підсумовуючи, слід зазначити, що система кадрового забезпечення освіти України потребує невідкладного реформування.

При цьому необхідним є проведення системної роботи у таких напрямах: розробка науково обгрунтованої концепції сучасної кадрової політики в освіті; удосконалення нормативно-правової та організаційної бази кадрової політики в освіті; модернізація системи неперервної професійної освіти педагогів.; співпраця держави і громадськості у напрямі прийняття та реалізації управлінських рішень, контролю за їх виконанням, участь в оцінці якості освіти споживачами освітніх послуг; підвищення ефективності фінансування освіти.

Отже, державна політика в галузі освіти - складова (підсистема) загальнодержавної політики, яка включає сукупність визначеної системи цілей, завдань, принципів, програм та основних напрямів діяльності органів управління освітою, спрямованих на організацію науково-методичного і впроваджувального супроводу стратегії розвитку освіти. Державну політику в галузі освіти України визначає вищий законодавчий орган, здійснюють органи державної виконавчої влади й органи місцевого самоврядування на основі затвердженої органами державної влади та схваленої громадською думкою концепції розвитку освіти.

\section{ЛIТЕРАТУРА}

1. Карпа М. Методи управління кадровими процесами у контексті становлення публічної служби в Україні // Ефективність державного управління : зб. наук. пр. ЛРІДУ НАДУ. - Вип. 37. - Львів: ЛРІ НАДУ, 2013. - 470с.

2. Ковбасюк Ю. В. Сучасна кадрова політика в державному управлінні / Ю. В. Ковбасюк // ВІЧЕ: громад.-політ. і теорем. вид. - 2011. - № 2. - С. 19-21.

3. Осійчук М. С. Модернізація кадрових служб як основа вдосконалення державного управління / М.С. Осійчук // Вісник державної служби України. - 2008. - № 3. - С. 27-33. 4. Osborne D. Reinventing Government / D. Osborne and T. Gaebler. - N.-Y., 1992. - P. 2-18, 44-69.

4. Капінус М. Р. Світові тенденції розвитку державної служби / М. Р. Капінус // Державна служба України в історичному контексті: проблеми становлення та розвитку : 12 матеріали наук.-практ. конф. до 90-річчя держ. служби України (Київ, 18 листоп. 2008 р.) : у 2 т. / за заг. ред. О. Ю. Оболенського, С. В. Сьоміна. - К. : НАДУ, 2009. - Т. 2 : у 3 ч. - Ч. 3. - 96 с.

5. Кіцак Т. Зарубіжні системи підготовки державних службовців / Т. Кіцак // Ефективність державного управління: зб. наук. пр. ЛРІДУ НАДУ. - Вип. 18/19 / за заг. ред. чл.-кор. НАН України В.С. Загорського, доц. А.В. Ліпенцева. - Львів: ЛРІДУ НАДУ, 2009. - 560 с.

6. Драган I. О. Підходи до удосконалення кадрового менеджменту в системі державної служби: аналіз зарубіжного досвіду / I. О. Драган // Державне управління: удосконалення та розвиток: електронне наукове фахове видання. - 2013. - № 1. 